\title{
ANALYSIS INFLUENCE RELATIONSHIP OF INTERNAL AND EXTERNAL ON STRATEGY AND SUSTAINABLE SUPPLY CHAINS MANAGEMENT ON OPERATIONAL PERFORMANCE OF FOOD AND BEVERAGES AGRO-INDUSTRIES
}

\author{
Dina Kartika Sari*, Djoko Koestiono, Agustina Shinta \\ Faculty of Agriculture, University of Brawijaya, Indonesian \\ *corresponding author: dinakartikasari17@gmail.com
}

\begin{abstract}
This research examines the influence of the relationship between internal and external factors on operational performance, beforehand an effective strategy supply chain management is needed to improve operational performance as a core strategic competency for better competitive advantage but companies need to evaluate actions that have environmental impacts, it is necessary practice sustainable supply chain management in a business. SEM-PLS analysis to examine the effect of the relationship between internal and external factor using a sample of 100 food and beverage agro-industries in the Province of East Java. The results showed that internal and external factors have a positive and significant effect on supply chain management strategy while on operational performance, although the influence of internal factors cannot be direct and external factors have a direct influence on operational performance, the practice sustainable supply chain management also has a direct effect as a mediating variable, between supply chain strategy variables on operational performance. This research is not only to find the right strategy for the food and beverage agro-industries but also to develop research on the importance of sustainable supply chain management practices in the food and beverage agro-industries.
\end{abstract}

Keywords: Factor Internal, Factor External, Supply Chain Management, Operational Performance, Agroindustries

http://dx.doi.org/10.21776/ub.agrise.2021.021.3.9

Received 6 April 2021

Accepted 7 July 2021

Available online 31 July 2021

\section{INTRODUCTION}

Economic development in the agricultural sector in Indonesia has formed a large proportion of the country's foreign exchange (Carolina, 2020). In 2018 national income in Indonesia was contributed by 34 provinces in Indonesia, with the top provinces which is DKI Jakarta, East Java and West Java (Katadata, 2019).
Table 1. GDP Distribution in Percentage by Business Field (2017-2018)

\begin{tabular}{lll}
\hline Province & 2017 & 2018 \\
\hline DKI Jakarta & 0,09 & 0,08 \\
East Java & 12,84 & 11,90 \\
West Java & 8,55 & 8,67 \\
\hline
\end{tabular}

Source : (BPS, 2019)

CITATION: Sari, D., K., Koestiono, D., Shinta, A., (2021). Analysis Influence Relationship of Internal and External on Strategy and Sustainable Supply Chains Management on Operational Performance of Food and Beverages AgroIndustries, Agricultural Socio-Economics Journal, 21(3), 241-250 DOI: 
In Table 1, it shows that East Java Province is the province with the most important role in the national economy compared to the other two provinces, especially in the agricultural sector.

In line with data from the East Java Bappreprov (Bank Dunia, 2011) as much as $74 \%$ of the East Java region is for agricultural cultivation, regional economic development in East Java is supported by areas in the agricultural sector.

The Regulation of the Ministry of Industry (2015) regarding the National Long-Term Development Plan 2005-2025 states that the economic structure is strengthened by placing the industrial sector as a driving force supported by agricultural activities in strengthening the economic structure in Indonesia.

Dewanti dan Santoso (2012) state that agroindustries is a mainstay sector in national economic development which is expected to process all agricultural products into semi-finished materials or final products involving human resources, agricultural commodities, capital, and technology. One of them is the agro-industries which until now has been projected by the government as a mainstay sector, which is food and beverage agroindustries. However, if you look at the contribution of the food and beverage agro-industries in the top provinces that contribute to GDP to the national economy, East Java Province has a lower percentage than West Java (Table 2).

Table 2. GDP Distribution in Percentage by Food and Beverage Processed Industry Business Field (2017-2018)

\begin{tabular}{ccc}
\hline Province & 2017 & 2018 \\
\hline DKI Jakarta & 7,40 & 7,38 \\
East Java & 9,23 & 9,80 \\
West Java & 11,06 & 11,10 \\
\hline
\end{tabular}

Source : (BPS, 2019)

In Table 2, it shows that is competition in increasing the regional economy even though East Java Province is the second largest contributor to GRDP, West Java is superior in the food and beverage agro-industries which can become a mainstay sector in increasing the national and regional economies. So the regional government of East Java needs to improve the performance of the agro-industries in order be able to compete more superiorly than West Java in the welfare of the regional economy.

This competition makes the food and beverage agro-industries players need to find a strategy that gives them a competitive advantage over competitors. One of them is an effective supply chain management strategy in improving the company's operational performance and achieving long-term goals as a core strategic competency to gain a competitive advantage with better company operational performance (Qrunfleh \& Tarafdar, 2013; Jermsittiparsert \& Rungsrisawat, 2019).

Before implementing a targeted supply chain management strategy, agro-industries entrepreneurs must consider the internal and external variables that drive changes to the supply chain management strategy (Sujono et al., 2013).

However, in the business context, business man should not only think about their own business but also evaluate actions within the company that can have an impact on the environment, therefore it is necessary to have practices sustainable supply chain management in a business (Wang et al., 2018).

Based on the above problems, the researcher needs to analyze the relationship between internal and external factors, supply chain management strategies, supply chain sustainability practices and operational performance in the food and beverage agro-industry in East Java, which aims to make local governments and food and beverage agro-industry entrepreneurs in East Java know the strategy. the. So that supply chain management can improve operational performance and be able to compete competitively.

\section{RESEARCH METHODS}

This type of research is an explanatory research that explains the relationship between variables with a quantitative approach that explains the relationship between variables; what decisions are studied; narrow and specific questions; data collection calculated from the number of respondents; using statistics by analyzing numbers, and seeing as a whole and objectively (Masri Singarimbun, 2011; Plano Clark et al., 2015)

Measurement of variables using the Likert scale 1-5, the Likert scale is used as a measure of attitudes, opinions, and perceptions of individuals or groups regarding a social event (Sugiyono, 2005; Kriyanto, 2006)

This research uses the SEM-PLS (Structural Equation Modeling-Partial Least Squares) method. In this research, there are 20 manifest variables, which are internal factors (5 items), external factors (4 items), supply chain management (2 items), practices practice sustainable supply chain management (4 items), operational performance (5 items). The model used to measure the five latent variables (Figure 1). 


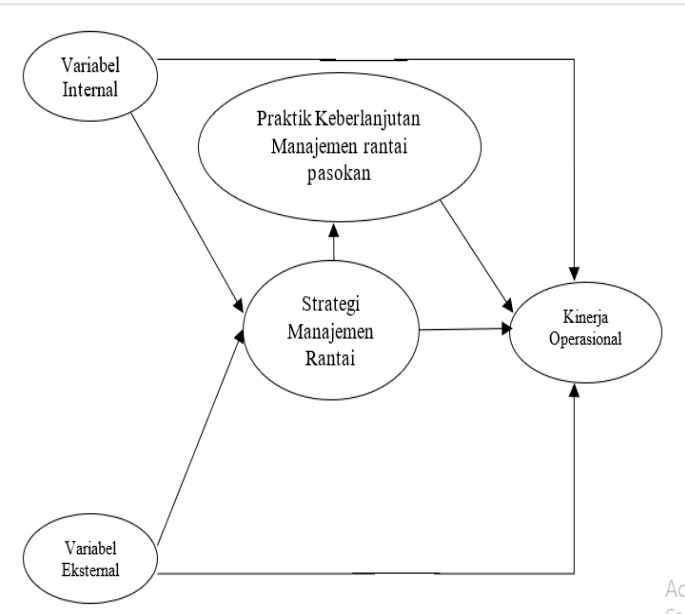

Figure 1. Source: Primary data, processed (2021)

\section{Sample and Data Collection}

In this research using probability sampling with one type of cluster random sampling because this technique is used when the population does not consist of individuals but from groups if the object or data to be studied is very broad (Sugiyono, 2005)

The sample used in the SEM-PLS (Structural Equation Modeling-Partial Least Squares) research is at least 30 to 100 respondents (Zuhdi et al., 2016) with the consideration that the level of accuracy of the data generated from the population is much better.

Solimun (2017) said to determine the sample size using a formula to calculate the sample size. The formula is adjusted to the sampling technique used and the information obtained. The sample was determined based on the Slovin formula with $\alpha=10 \%$, as many as 100 food and beverage agro-industries spread over several districts and cities with probability sampling in this study was cluster random sampling (Sugiyono, 2005) in East Java.

The distribution of questionnaires that were arranged deliberately randomly searched through the internet media (google) and filled in online for approximately one month between February and March 2021 so as to produce validity and reliability in the study.

\section{Data Analysis Techniques}

The analysis tool in this research uses Structural Equation Modeling (SEM) in testing and estimating the causal relationship between variables by integrating variable analysis and path analysis (Abdillah et al., 2015).

Hair Jr et al. (2014) stated that SEM has the ability to analyze the pattern of relationships in latent constructs and their manifestations, latent constructs with each other, and direct measurement errors.

Partial Least Square is a multivariate statistical technique that makes comparisons between multiple dependent variables and multiple independent variables, PLS is also a variant-based SEM statistical method designed to solve multiple regression when there are specific problems with data, such as small sample sizes, and the presence of data. missing values, and multikiolinearity. (Abdillah et al., 2015)

Data analysis in this research is using Structural Equation Modeling-Partial Least Square (SEM-PLS) with the WarpPLS approach. The first step carried out with WarpPLS is to create a path diagram consisting of a structural model (inner model) and a measurement model (outer model). The structural model explains the relationship between exogenous latent variables and endogenous latent variables. The measurement model is the relationship between manifest variables and latent variables.

\section{RESULTS AND DISCUSSION}

\section{Food and Beverage Agro-industries's Profile}

In this study the respondents taken were small-scale food and beverage agro-industries or MSE (Micro-Small Enterprises) in East Java. Respondents in this research were located in 34 cities and districts, except for Blitar, Mojokerto, Madiun, and Batu cities.

The respondents in this research were 100 food and beverage agro-industries with a total of 50 food and beverage agro-industries.

In the agro-industries of processed food which is based on agricultural commodities, in this study there are very diverse such as processed cassava and sweet potato, bananas, glutinous rice, nuts such as tempeh and tofu chips, as well as various chili preparations into chili sauce and other sauces.

In the processed beverage agro-industries there are also various types of processed drinks such as soybean milk, star fruit, pineapple, melon, various traditional drinks made from spices such as ginger, turmeric, and others, then various processed tea, coffee and other drinks.

\section{Validity and Reliability}

Solimun (2017) states that testing the validity and reliability of the research latent variable indicators, the reflective model has internal consistency reliability criteria, seen that the composite reliability value must be greater than 0.7 ( $\rho c>0.7$ ). The measure of the reliability of the questionnaire, namely Cronbach's Alpha is greater than $0.60(\alpha>0.60)$, it is said that the questionnaire 
is reliable. The value of Convergent validity seen from the Average Variance Extracted (AVE) value must be greater than 0.5 , meaning that $50 \%$ or more of the variance of the indicator can be explained (Table 3)

Discriminate validity of each indicator (Table 4) is seen from the loading and cross loading factor values, if the loading value of each indicator is greater than the cross loading then the latent variable is discriminant validity, in discriminant validity for all AVE squared comparison questionnaires. each construct with a correlation value between constructs in the model. If the AVE squared value for each latent variable is greater than the correlation between variables in the model, then the indicators in the questionnaire have met the criteria. (Solimun, 2017).

Table 3. Internal Consistency Reliability and Convergent Validity

\begin{tabular}{|c|c|c|}
\hline & & Loading \\
\hline \multirow{5}{*}{$\begin{array}{l}\text { Internal Factors }(X 1) \\
(\rho c=0,847 ; \alpha=0,771 ; A V E=0,533)\end{array}$} & $\mathrm{X} 1.1$ & 0,783 \\
\hline & $\mathrm{X} 1.2$ & 0,767 \\
\hline & $\mathrm{X} 1.3$ & 0,827 \\
\hline & $\mathrm{X} 1.4$ & 0,472 \\
\hline & $\mathrm{X} 1.5$ & 0,746 \\
\hline \multirow{4}{*}{$\begin{array}{l}\text { External factors }(X 2) \\
(\rho c=0,883 ; \alpha=0,819 ; \mathrm{AVE}=0,658)\end{array}$} & $\mathrm{X} 2.1$ & 0,908 \\
\hline & $\mathrm{X} 2.2$ & 0,641 \\
\hline & $\mathrm{X} 2.3$ & 0,737 \\
\hline & $\mathrm{X} 2.4$ & 0,924 \\
\hline \multirow{2}{*}{$\begin{array}{l}\text { Supply Chain Management (Y1) } \\
(\rho c=0,836 ; \alpha=0,609 ; \mathrm{AVE}=0,719)\end{array}$} & Y1.1 & 0,848 \\
\hline & Y1.2 & 0,848 \\
\hline \multirow{4}{*}{$\begin{array}{l}\text { Practices Sustainable Supply Chain Management } \\
(\mathrm{Y} 2) \\
(\rho \mathrm{c}=0,816 ; \alpha=0,699 ; \mathrm{AVE}=0,528)\end{array}$} & Y2.1 & 0,613 \\
\hline & Y2.2 & 0,768 \\
\hline & Y2.3 & 0,760 \\
\hline & Y2.4 & 0,755 \\
\hline \multirow{5}{*}{$\begin{array}{l}\text { Operationel Perfomance }(\mathrm{Y} 3) \\
(\rho \mathrm{c}=0,916 ; \alpha=0,882 ; \mathrm{AVE}=0,688)\end{array}$} & Y3.1 & 0,930 \\
\hline & Y3.2 & 0,667 \\
\hline & Y3.3 & 0,743 \\
\hline & Y3.4 & 0,873 \\
\hline & Y3.5 & 0,904 \\
\hline
\end{tabular}

Note: Composite reliability $(\rho c) \geq 0.7$; Cronbach's alpha $(\alpha) \geq 0.70$; Average variance extracted $(\mathrm{AVE}) \geq 0.50$; Loading factor $\geq 0.30$

Source: Primary data, processed (2021)

Table 4. Discriminant Validity

\begin{tabular}{l|l|l|l|l|l}
\hline & X1 & X2 & Y1 & Y2 & Y3 \\
\hline Internal factor & $\mathbf{( 0 , 7 3 0 )}$ & 0,379 & 0,592 & 0,433 & 0,372 \\
\hline External factor & 0,379 & $\mathbf{( 0 , 8 1 1 )}$ & 0,398 & 0,371 & 0,471 \\
\hline Supply Chain Management & 0,592 & 0,398 & $\mathbf{( 0 , 8 4 8 )}$ & 0,358 & 0,384 \\
\hline Practice Sustainable Supply Chan & 0,433 & 0,371 & 0,358 & $\mathbf{( 0 , 7 2 7 )}$ & 0,553 \\
\hline Operational Performance & 0,372 & 0,471 & 0,384 & 0,553 & $\mathbf{( 0 , 8 3 0 )}$ \\
\hline
\end{tabular}

Source: Primary data, processed (2021)

\section{Stuctural Model}

In the structural model, the results of $\mathrm{R}^{2}$ are used to viewt many variations presented for each variable which is determined as the predictive power of the inner model. There are 3 classifications on the $\mathrm{R}^{2}$ value, which is $0.70 ; 0.45$; and 0.25 which indicates that the model is strong, moderate and weak.
Results $\mathrm{Q}^{2}$ predictive relevance in order to see whether a model has predictive relevance or not. The value in $\mathrm{Q}^{2}$ is greater than $0\left(\mathrm{Q}^{2}<0\right)$ indicates that the model has predictive relevance (Table 5). 
Table 5. $\mathrm{R}$-square $\left(\mathrm{R}^{2}\right)$ dan $\mathrm{Q}^{2}$ predictive relevance

\begin{tabular}{l|l|l|l}
\hline \multicolumn{1}{c|}{ Indikator } & $\mathrm{Y} 1$ & $\mathrm{Y} 2$ & $\mathrm{Y} 3$ \\
\hline $\mathrm{R}-$ Square $\left(\mathrm{R}^{2}\right)$ & 0,420 & 0,144 & 0,410 \\
\hline $\begin{array}{l}\mathrm{Q}^{2} \text { predictive } \\
\text { relevance }\end{array}$ & 0,433 & 0,147 & 0,417 \\
\hline Seurce: Primary data & & & \\
\hline
\end{tabular}

Source: Primary data, processed (2021)

To see the existence of Full collinearity VIF which is carried out for full collinearity testing on vertical and lateral multicollinearity, this test has a criterion value of more than $3.3(<3,3)$ so that the meaning of the model is free from bias in vertical and lateral collinerity problems (Table 6).

Table 6. Full Collin. VIF

\begin{tabular}{l|l}
\hline Indicator & Full Collin. VIF \\
\hline X1 & 1,663 \\
\hline X2 & 1,589 \\
\hline Y1 & 1,803 \\
\hline Y2 & 1,709 \\
\hline Y3 & 2,494 \\
\hline
\end{tabular}

Source: Primary data, processed (2021)

The effect size $\left(\mathrm{f}^{2}\right)$ is used to see the amount of variation in exogenous variables with the criteria for the value of an effect size of 0.02 (small), 0.15 (medium), and 0.35 (large). (Table 7)

Table 7. Effect Size

\begin{tabular}{l|l|l|l|l|l}
\hline & \multicolumn{5}{|c}{ Effect Sizes $\left(\mathrm{f}^{2}\right)$} \\
\hline & X1 & X2 & Y1 & Y2 & Y3 \\
\hline Y1 & 0,314 & 0,106 & & & \\
\hline Y2 & & & 0,144 & & \\
\hline Y3 & 0,020 & 0,118 & 0,051 & 0,220 & \\
\hline
\end{tabular}

Source: Primary data, processed (2021)

\section{Mediation Model Analysis}

According to Solimun (2017) criteria:

a. The results of the 1 coefficient analysis must be significant; b. If p3 and p4 are significant, but p2 is not significant, then the SCM strategy is said to be a complete mediating variable; c. If $\mathrm{p} 3$ and $\mathrm{p} 4$ are significant, and p2 is also significant, where the path coefficient $\mathrm{p} 2$ is smaller than $\mathrm{p} 1$, then the SCM strategy is said to be partially mediated; $d$. If p3 and p4 are significant, and p2 is also significant, where the path coefficient $\mathrm{p} 2$ is almost the same as $\mathrm{p} 1$, then the SCM strategy is said to be not the mediating variable; e. If p3 and p4 are not significant, then it is said that the SCM strategy is not a mediating variable.

Following are the path coefficients and $\mathrm{P}$ values when the mediating variable is excluded from the model and when the mediating variable is included in the model (Table 8).

\section{Hypotheses Testing}

Hypothesis testing in this research used resampling Stable 3 to see the path coefficient and P-value at significant levels of $5 \%$ and $10 \%$. Requirements for the P-value must be less than 0.05 and 0.1 which means significant is accepted (Table 9).

\section{Discussion and Implications}

Based on the results of research using SEM-PLS analysis, it shows the comparison of previous studies that have the same structural model, different in the structural model in this research the researcher developed a linkage of supply chain management strategy with sustainable supply chain management practices that previously did not have this linkage research, this is create new paths from previous research.

Practice sustainable supply chain management mediate between strategy supply chain management and operational performance, because it can be seen that is a significant weak influence on strategy supply chain management on operational performance, but when going through the mediating variable, which is practice sustainable supply chain management, the effect is significantly stronger with an indirect effect.

Table 8. Nilai Path Coefficient and P-value Excluded-Included

\begin{tabular}{|c|c|c|c|c|c|c|}
\hline \multirow{2}{*}{ Path } & \multicolumn{2}{|c|}{ Direct Path Coefficient } & \multirow{2}{*}{$\begin{array}{l}\text { Indirect } \\
\text { Path } \\
\text { Coefficient }\end{array}$} & \multicolumn{2}{|c|}{ P-value } & \multirow[t]{2}{*}{ Interpretation } \\
\hline & Excluded & Included & & Excluded & Included & \\
\hline $\mathrm{X} 1 \rightarrow \mathrm{Y} 3$ & 0,387 & 0,234 & 0,153 & $<0,001$ & 0,007 & partially mediated \\
\hline $\mathrm{X} 2 \rightarrow \mathrm{Y} 3$ & 0,472 & 0,368 & 0,104 & $<0,001$ & $<0,001$ & partially mediated \\
\hline $\mathrm{Y} 1 \rightarrow \mathrm{Y} 3$ & 0,405 & 0,229 & 0,176 & $<0,001$ & 0,008 & partially mediated \\
\hline
\end{tabular}

Source: Primary data, processed (2021) 
Table 9. Hypotheses Testing

\begin{tabular}{l|l|l|l}
\hline & $\boldsymbol{\beta}$ & P-value & Hypothesis \\
\hline $\mathrm{X} 1 \rightarrow \mathrm{Y} 1$ & 0,515 & $<0,001$ & Supported \\
\hline $\mathrm{X} 1 \rightarrow \mathrm{Y} 3$ & 0,052 & 0,299 & Not supported \\
\hline $\mathrm{X} 2 \rightarrow \mathrm{Y} 1$ & 0,240 & 0,006 & Supported \\
\hline $\mathrm{X} 2 \rightarrow \mathrm{Y} 3$ & 0,251 & 0,004 & Supported \\
\hline $\mathrm{Y} 1 \rightarrow \mathrm{Y} 2$ & 0,379 & $<0,001$ & Supported \\
\hline $\mathrm{Y} 1 \rightarrow \mathrm{Y} 3$ & 0,127 & 0,096 & Supported \\
\hline $\mathrm{Y} 2 \rightarrow \mathrm{Y} 3$ & 0,394 & $<0,001$ & Supported \\
\hline
\end{tabular}

Source: Primary data, processed (2021)

This proves Hasan (2017) theory that the existence of practice sustainable supply chain management can increase efficiency, reduce costs, improve services, increase sales and market share, and increase reputation because companies are responsible for the sustainability dimension in operational performance.

It is known that this study has a significant effect on tolerance of more than 0.1 (10\%) between internal factors and operational performance even though it has a positive relationship, this is the same as research Sujono et al. (2013) which means that reduction or addition to internal factors has no effect on operational performance, it needs no influence. direct between internal factors and operational performance through a supply chain strategy.

Supported by a developing theory (Prajogo \& Olhager, 2012; Qi et al., 2017; Ralston et al., 2015) states that the supply chain management framework of the industry acts as a complement to achieve higher performance which has a positive effect which generally provides important procedures for managers to build longterm competence between supply chain management strategy and future operational performance. Therefore, the food and beverage agro-industry in East Java needs to align internal and external factors into an effective supply chain management strategy by taking into account the sustainability of supply chain management practices to improve company performance in the future.

\section{CONCLUSION}

Based on research conducted on the influence of internal and external factors on supply chain management strategy, it has been tested empirically in this study, and theoretically supports the theory of developing a strategy supply chain management with the research results that internal and external factors have a positive and significant effect on strategy supply chain management. whereas in operational performance, although the influence of internal factors cannot be direct and external factors have a direct influence on operational performance, the practice sustainable supply chain management also has a direct effect as a mediating variable between the variables of strategy supply chain management on operational performance.

\section{BIBLIOGRAPHY}

Abdillah, W., Hartono, J., \& Prabantini, D. (2015). Partial Least Square (PLS): alternatif Structural Equation Modeling (SEM) dalam penelitian bisnis. Penerbit Andi.

Badan Pusat Statistik. (2019). Keadaan Industry Menurut Kelompok Industry Besar Sedang di provinsi Jawa Timur. https://jatim.bps.go.id/statictable/2019/10/09/ 1666/keadaan-industri-menurut-kelompokindustri-besar-sedang-di-provinsi-jawa-timur2018.html.

Bank Dunia. (2011). Mengoptimalkan Pengelolaan Keuangan Daerah untuk Pertumbuhan yang Inklusif.

Dewanti dan Santoso. (2012). Penentuan Alternatif Lokasi Pengembangan Kawasan Agroindustri Berbasis Komoditas Pertanian Unggulan Di Kabupaten Lamongan. Jurnal Teknik ITS, I(Vol 1, No 1 (2012): Jurnal Teknik ITS (ISSN 2301-9271)), C33-C37. http://ejurnal.its.ac.id/index.php/teknik/article/ view/925.

F. Hair Jr, J., Sarstedt, M., Hopkins, L., \& G. Kuppelwieser, V. (2014). Partial least squares structural equation modeling (PLS-SEM). European Business Review, 26(2), 106-121. https://doi.org/10.1108/EBR-10-2013-0128

Hasan, M. (2017). Sustainable Supply Chain Management Practices and Operational Performance. January 2013. https://doi.org/10.4236/ajibm.2013.31006.

Jermsittiparsert, K., \& Rungsrisawat, S. (2019). The Supply Chain Management and Information Sharing As Antecedents of Operational Performance: August. https://doi.org/10.18510/hssr.2019.7258.

Katadata, D. (2019). PDRB 34 Provinsi di Indonesia. 
https://databoks.katadata.co.id/datapublish/20 19/07/31/inilah-pdrb-34-provinsi-diindonesia-pada-2018.

Kementrian Perindustrian. (2015). Rencana Strategis Direktorat Jendral Industri Agro 2015-2019.

Masri Singarimbun, S. E. (2011). Metode Penelitian Survei. LP3ES.

Plano Clark, V. L., Anderson, N., Wertz, J. A., Zhou, Y., Schumacher, K., \& Miaskowski, C. (2015). Conceptualizing Longitudinal Mixed Methods Designs: A Methodological Review of Health Sciences Research. Journal of Mixed Methods Research, 9(4), 297-319. https://doi.org/10.1177/1558689814543563.

Prajogo, D., \& Olhager, J. (2012). Supply chain integration and performance: The effects of long-term relationships, information technology and sharing, and logistics integration. International Journal of Production Economics, 135(1), 514-522. https://doi.org/10.1016/j.ijpe.2011.09.001

Qi, Y., Huo, B., Wang, Z., \& Yeung, H. Y. J. (2017). The impact of operations and supply chain strategies on integration and performance. International Journal of Production Economics, 185(December 2015), 162-174.

https://doi.org/10.1016/j.ijpe.2016.12.028.

Qrunfleh, S., \& Tarafdar, M. (2013). Lean and agile supply chain strategies and supply chain responsiveness: The role of strategic supplier partnership and postponement. Supply Chain Management: An International Journal, 18(6), 571-582. https://doi.org/10.1108/SCM01-2013-0015
Kriyanto, R. (2006). Teknik Praktis Riset Komunikasi. kencana. Prenada Media Group.

Ralston, P. M., Blackhurst, J., Cantor, D. E., \& Crum, M. R. (2015). A Structure-conductperformance perspective of how strategic supply chain integration affects firm performance. Journal of Supply Chain Management, 51(2), 47-64. https://doi.org/10.1111/jscm.12064.

Solimun, Achmad Rinaldo Fernandes Adji, and N. (2017). Metode Statistika Multivariat Pemodelan Persamaan Struktural (SEM). UB Press.

Sugiyono. (2005). Metode Penelitian Bisnis. CV Alfabeta.

Sujono, S., Rahardjo, K., \& Utami, H. N. (2013). The Influence of Internal Drivers and Environmental Drivers towards Supply Chain Management ( SCM ) Strategy , SCM Practices, Responsiveness and Implication on the Operational Performance of Organic Fertilizer Manufacturers in East Java , Indonesia. 3(12), 40-53.

Wang, J., Zhang, Y., \& Goh, M. (2018). Moderating the role of firm size in sustainable performance improvement through sustainable supply chain management. Sustainability (Switzerland), 10(5). https://doi.org/10.3390/su10051654.

Zuhdi, Z., Suharjo, B., \& Sumarno, H. (2016). Perbandingan Pendugaan Parameter Koefisien Struktural Model Melalui Sem Dan Pls-Sem. Journal of Mathematics and Its Applications, 15(2), 11 . https://doi.org/10.29244/jmap.15.2.11-22. 
Appendix 1. Indicator loading and Cross loading

\begin{tabular}{|c|c|c|c|c|c|c|c|c|}
\hline & $\mathrm{X} 1$ & X2 & Y1 & Y2 & Y3 & Type (as defined) & SE & Pvalue \\
\hline $\mathrm{X} 1.1$ & $(0.783)$ & -0.026 & -0.242 & -0.139 & 0.253 & Reflective & 0.081 & $<0.001$ \\
\hline $\mathrm{X} 1.2$ & $(0.767)$ & -0.021 & 0.089 & 0.135 & 0.054 & Reflective & 0.081 & $<0.001$ \\
\hline $\mathrm{X} 1.3$ & $(0.827)$ & -0.092 & 0.382 & 0.064 & -0.148 & Reflective & 0.080 & $<0.001$ \\
\hline $\mathrm{X} 1.4$ & $(0.472)$ & 0.188 & -0.369 & 0.115 & -0.303 & Reflective & 0.088 & $<0.001$ \\
\hline $\mathrm{X} 1.5$ & $(0.746)$ & 0.032 & -0.027 & -0.137 & 0.034 & Reflective & 0.082 & $<0.001$ \\
\hline$X 2.1$ & -0.143 & $(0.908)$ & 0.088 & 0.000 & -0.119 & Reflective & 0.078 & $<0.001$ \\
\hline$\times 2.2$ & 0.167 & $(0.641)$ & -0.127 & 0.082 & 0.073 & Reflective & 0.084 & $<0.001$ \\
\hline $\mathrm{X} 2.3$ & 0.139 & $(0.737)$ & -0.094 & -0.075 & 0.227 & Reflective & 0.082 & $<0.001$ \\
\hline$X 2.4$ & -0.088 & $(0.924)$ & 0.076 & 0.003 & -0.115 & Reflective & 0.078 & $<0.001$ \\
\hline $\mathrm{Y} 1.1$ & -0.076 & -0.014 & $(0.848)$ & 0.056 & -0.172 & Reflective & 0.079 & $<0.001$ \\
\hline $\mathrm{Y} 1.2$ & 0.076 & 0.014 & $(0.848)$ & -0.056 & 0.172 & Reflective & 0.079 & $<0.001$ \\
\hline Y2.1 & 0.024 & -0.165 & -0.181 & $(0.613)$ & 0.001 & Reflective & 0.085 & $<0.001$ \\
\hline Y2.2 & 0.023 & 0.090 & 0.013 & $(0.768)$ & 0.245 & Reflective & 0.081 & $<0.001$ \\
\hline Y2.3 & -0.193 & 0.265 & 0.079 & $(0.760)$ & -0.064 & Reflective & 0.081 & $<0.001$ \\
\hline Y2.4 & 0.151 & -0.224 & 0.055 & $(0.755)$ & -0.185 & Reflective & 0.081 & $<0.001$ \\
\hline Y3.1 & -0.012 & 0.009 & 0.126 & 0.041 & $(0.930)$ & Reflective & 0.078 & $<0.001$ \\
\hline Y3.2 & -0.072 & 0.254 & 0.012 & 0.054 & $(0.667)$ & Reflective & 0.083 & $<0.001$ \\
\hline Y3.3 & -0.229 & -0.061 & 0.103 & -0.042 & $(0.743)$ & Reflective & 0.082 & $<0.001$ \\
\hline Y3.4 & 0.207 & -0.030 & -0.159 & -0.017 & $(0.873)$ & Reflective & 0.079 & $<0.001$ \\
\hline Y3.5 & 0.054 & -0.118 & -0.070 & -0.031 & $(0.904)$ & Reflective & 0.078 & $<0.001$ \\
\hline
\end{tabular}

\section{Appendix 2. Latent Variable Coefficient}

\begin{tabular}{|c|c|c|c|c|c|c|}
\hline & $\mathrm{X} 1$ & $X 2$ & Y1 & Y2 & $\mathrm{Y} 3$ & \\
\hline R-squared & & & 0.420 & 0.144 & 0.410 & \\
\hline Adj. R-squared & & & 0.408 & 0.135 & 0.385 & \\
\hline Composite reliab. & 0.847 & 0.883 & 0.836 & 0.816 & 0.916 & \\
\hline Cronbach's alpha & 0.771 & 0.819 & 0.609 & 0.699 & 0.882 & \\
\hline Avg. var. extrac. & 0.533 & 0.658 & 0.719 & 0.528 & 0.688 & \\
\hline Full collin. VIF & 1.713 & 1.417 & 1.663 & 1.589 & 1.672 & \\
\hline Q-squared & & & 0.433 & 0.147 & 0.417 & \\
\hline Min & -1.798 & -2.963 & -2.866 & -2.178 & -2.760 & \\
\hline Max & 2.312 & 2.814 & 1.771 & 1.827 & 2.387 & \\
\hline Median & 0.078 & -0.100 & 0.225 & 0.115 & 0.055 & \\
\hline Mode & 0.450 & -0.799 & 0.225 & 0.115 & 0.751 & \\
\hline Skewness & 0.402 & 0.203 & -0.414 & 0.024 & -0.029 & \\
\hline Exc. kurtosis & -0.291 & 0.588 & 0.204 & -0.273 & 0.367 & \\
\hline Unimodal-RS & Yes & Yes & Yes & Yes & Yes & \\
\hline Unimodal-KMV & Yes & Yes & Yes & Yes & Yes & \\
\hline Normal-JB & Yes & Yes & Yes & Yes & Yes & \\
\hline Normal-RIB & Yes & Yes & No & Yes & Yes & \\
\hline Histogram & View & View & View & View & View & \\
\hline
\end{tabular}

Notes: Unimodal-RS = Rohatgi-Sz $\square$ kely test of unimodality; Unimodal-KMV = Klassen-Mokveld-van Es test of unimodality; Normal-JB $=$ Jarque $\square B e r a$ test of normality; Normal-RJB = robust Jarque $\square$ Bera test of normality; click on "View" cell to see corresponding histogram. 
Appendix 3. Model fit and Quality indices

\section{Model fit and quality indices}

Average path coefficient $(A P C)=0.280, P<0.001$

Average R-squared (ARS) $=0.325, P<0.001$

Average adjusted R-squared (AARS) $=0.310, P<0.001$

Average block VIF (AVIF) $=1.375$, acceptable if $<=5$, ideally $<=3.3$

Average full collinearity VIF (AFVIF) $=1.611$, acceptable if $<=5$, ideally $<=3.3$

Tenenhaus GoF (GoF) $=0.451$, small $>=0.1$, medium $>=0.25$, large $>=0.36$

Sympson's paradox ratio $(S P R)=1.000$, acceptable if $>=0.7$, ideally $=1$

R-squared contribution ratio $(R S C R)=1.000$, acceptable if $>=0.9$, ideally $=1$

Statistical suppression ratio $(\mathrm{SSR})=1.000$, acceptable if $>=0.7$

Nonlinear bivariate causality direction ratio $(N L B C D R)=1.000$, acceptable if $>=0.7$

Appendix 4. Structural Model

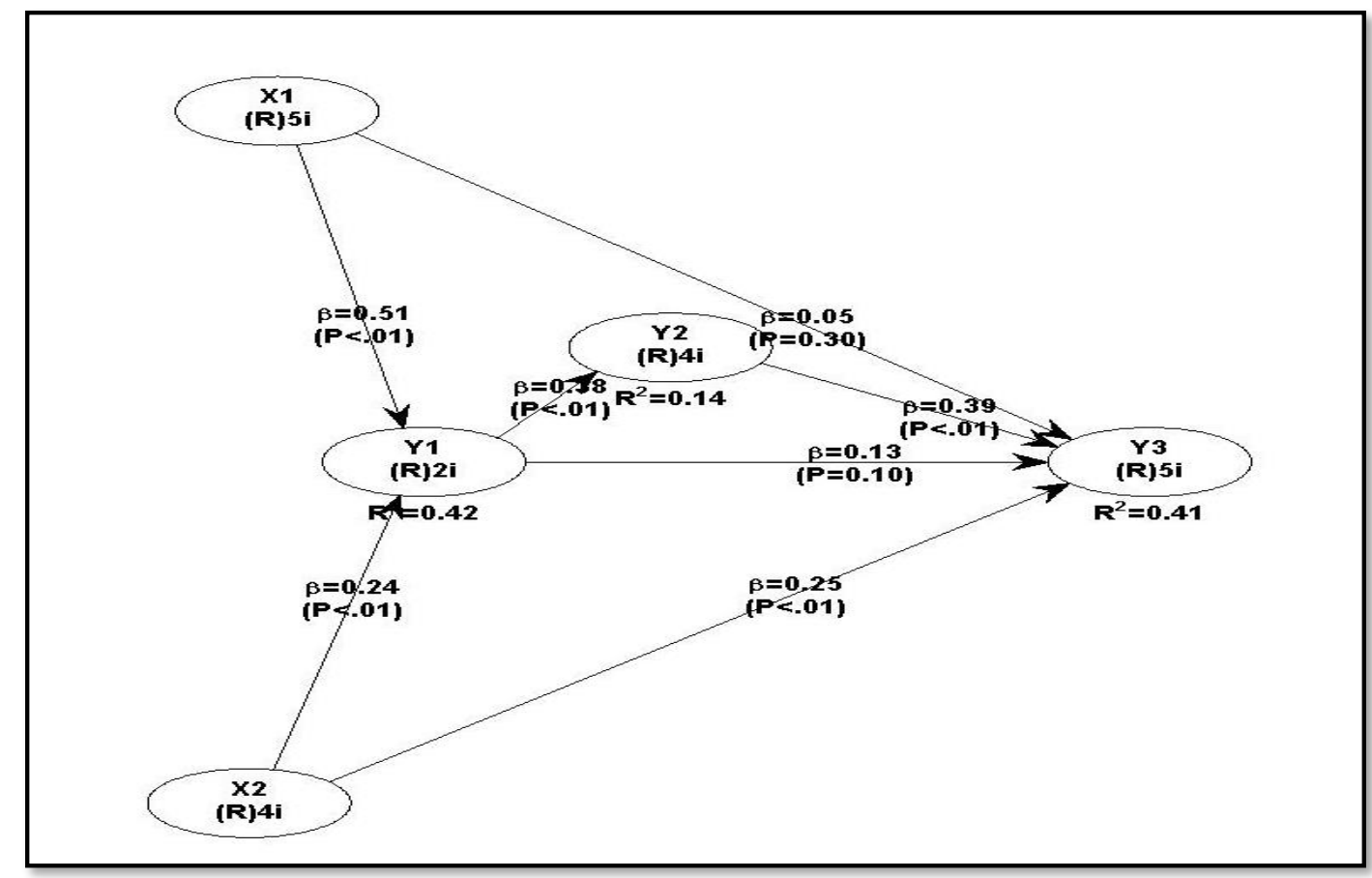


This page is intentionally left blank 